\title{
Transitivity in Brazilian Greenpeace's electronic bulletins
}

\section{Transitividade em Boletins eletrônicos do Greenpeace}

Rodrigo Esteves de Lima-Lopes

Universidade Federal da Paraíba

João Pessoa - Paraíba / Brasil

RESUMO: Este artigo tem como objetivo analisar as escolhas de transitividade em 21 boletins eletrônicos do Greenpeace escritos em Português do Brasil. O referencial teórico está na Gramática Sistêmico-Funcional (HALLIDAY, 1994; HALLIDAY \& MATTHIESSEN, 1999; HALLIDAY \& MATTHIESSEN, 2004). A Linguística de Corpus foi utilizada como ferramenta metodológica principal, o que inclui um concordanciador e um sistema de etiquetagem. Como os resultados mostraram, estes textos desenham uma representação textual em que cada uma das entidades representadas possui um papel específico. Afiliados ao Greenpeace, por exemplo, são geralmente retratados como defensores da causa do verde, ao passo que empresas são comumente classificadas como vilóes que não se importam com o meio ambiente. Cada uma dessas representaçôes é acompanhada por um padrão gramatical.

PALAVRAS-CHAVE: transitividade, gramática sistêmico-funcional, discurso verde, linguística de corpus, Greenpeace.

ABSTRACT: This article aims to analyse transitivity choices in 21 Greenpeace electronic bulletins written in Brazilian Portuguese. The theoretical framework is based on Systemic-Functional Grammar (HALLIDAY, 1994; HALLIDAY \& MATTHIESSEN, 1999, 2004). Corpus Linguistics was the main methodological tool, in which concordancers and a tag system were applied. As results indicated, these texts draw a textual representation in which each of the text entities plays a specific role. People affiliated with Greenpeace, for example, are commonly portrayed as advocates of green causes, while companies are commonly represented as villains who care nothing about the environment. Each of these representations is accompanied by specific grammatical patterns.

KEYWORDS: transitivity, systemic functional grammar, green discourse, corpus linguistics, Greenpeace.

* rodrigo@cchla.ufpb.br 


\section{Context and motivation}

In this paper, I analyse transitivity choices (HALLIDAY \& MATTHIESSEN, 2004) in order to understand how Greenpeace, its affiliates, governments and a number of different companies/institutions are represented in a corpus of 21 Greenpeace electronic bulletins, all written in Brazilian Portuguese. My hypothesis is that these representations are part of a discourse strategy that aims to legitimize Greenpeace's propaganda (FAIRCLOUGH, 2001).

The theoretical background is based on the Systemic Functional Grammar (SFL), developed by Michael Halliday (HALLIDAY, 1973, 1978, 1985, 1992b, 1993, 1994; HALLIDAY \& MATTHIESSEN, 1999; HALLIDAY \& MATTHIESSEN, 2004) and followers (EGGINS, 1994; MARTIN, MATTHIESSEN \& PAINTER, 1997; THOMPSON, 1996, 2004). SFL explains how language is structured as a semiotic system in different social contexts (EGGINS, 1994, p. 22-23), and sees it as a meaningmaking device deeply related to the social context around it (THOMPSON, 1998, p. 30). This means that SFL is an approach to linguistic description that explores not only the possible structures, but also how speakers organise the relevant linguistics options in each context (THOMPSON, 1996, p. 8-9). In other words, when the speaker makes language choices, he/she is performing a social act, which might have a number of specific social and interactional consequences. These acts are influenced by the culture and situation contexts, and each choice has a specific value when compared to others. When making a choice, the speaker is also choosing not to use a number of wordings (HALLIDAY, 1991, 1992a, 1993; STUBBS, 1996).

According to Halliday (1994, p. 106, 170), our most powerful way of representing experience lies within the acknowledgment of events - such as happening, sensing, meaning, being and becoming. The grammatical system by which it can be accomplished is entitled Transitivity, which is responsible for building a representational world in order to ascribe meaning to our experiences. The basic constituents of a proposition in this system are: 1) the process, 2) its participants and 3) circumstantial elements. The process is always represented by the verbal component; the participants are usually represented by nouns (or other elements working as such), which either carry out or are affected by the process; the circumstantial elements are responsible for encoding the background against which the process takes place.

This system is responsible for transforming both our inner and outer experiences into a tangible number of process types, participants and 
circumstances (HALLIDAY, 1985, 1994; HALLIDAY \& MATTHIESSEN, 1999; HALLIDAY \& MATTHIESSEN, 2004). For Halliday, there are six types of processes:

1. Material processes, which represent our experience in the outer and physical world, and are instantiated by concrete and tangible doings/goings-on.

2. Mental processes represent experiences in our inner world, instantiated in our own consciousness, actions of sensing, feeling and thinking.

3. Relational processes represent meanings related to identification, attribution and ownership.

4. Behavioural processes lie on the borderline between the material and the mental. These actualise mental process which are externalised.

5. Verbal processes are between the mental and the relational. These can be described as responsible for symbolic relationships that take place in our conscience but that are instantiated through verbal language.

6. Finally, existential processes are related to any kind of phenomenon recognised as existent.

Some studies on Brazilian Portuguese include Rodrigues Junior (2006), who compares transitivity choices in American gay short stories and their translations into Portuguese; Bressane (2000), who analyses a meeting in a real estate company; Heberle (1999), who discusses how women are portrayed in a Brazilian woman's magazine; Lima-Lopes (LIMA-LOPES, 2001, 2005b; LIMA-LOPES \& VENTURA, 2008), who investigate transitivity in direct sales letters; and Armbrust (2006), who compares Portuguese and English passive voices. In general, these studies draw some important results regarding this system in Portuguese, such as how grammatical structures can mirror ideological and social views.

Brazil is a large country and is well-known for its natural resources; however, environmental issues have received little attention until recently; in the last few decades, there has been an increasing interest in preservation and sustainable growth. Such a change has brought some alterations to Brazilian society: in the 70's, the Brazilian Federal Government, all Brazilian States and many of our largest cities created special departments to deal with environmental issues. One example would be the case of São Paulo, the largest city in the country with over 10 million people, where a State Department controls the pollution that results from companies' activities, as well as the 
$\mathrm{CO}_{2}$ levels produced by automobiles and other vehicles, by establishing severe laws and regulations. The United Nations Conference on Development and the Environment, which took place in Rio de Janeiro in 1992, was another example of such change. In the last 30 years or so, many new environmental conservation units - such as parks and reserves - were created and many animals are now under protection. All these changes have also made it possible for the creation of a new industry in the country, locally called Ecoturismo.

While some preservationist actions have been implemented, the situation in Brazil is far from perfect: the Brazilian government lacks enforcement resources and political issues are still a problem, since Brazil is still trying to concatenate its growth through economic policies to environmental preservation. This scenario is a rich field for the blossoming of many green organisations, which lately have become part of Brazilian daily life. We can list some examples: SOS Mata Atlântica, which aims to save the rainforest; Projeto Tamar, whose members work on projects to preserve the life of sea turtles on the Brazilian coast; WWF and Greenpeace, two of the biggest international green organisations; amongst many others.

My interest in this issue comes from the fact that I used to be a supporter of such a cause. From 2001 to 2007, I was affiliated with Greenpeace and I noticed that it establishes a direct and frequent contact with their supporters through PDF reports, e-mail bulletins, forums and a number of other genres and media. Such a contact seems to be a way of making its work known by individuals; each Rainbow Warrior (a general name given to a Greenpeace supporter) receives at least one electronic bulletin per week, together with many extra bulletins, bringing various campaign details. Most of these documents have never been studied in Portuguese.

It is therefore expected that these various publications are responsible for spreading Greenpeace's political views, which create within themselves a textual universe that is ideologically motivated. Within this universe the different entities represented there - such as its affiliates, governments and their actions for or against green causes, and several private companies - should play some discourse role.

\section{Methods}

The corpus analysed in this paper consists of 21 Greenpeace electronic bulletins written in Brazilian Portuguese and delivered via e-mail between 2003 and 2006. Details on the corpus are shown on Table 1. 


\section{TABLE 1}

\begin{tabular}{l|r}
\multicolumn{2}{c}{ Corpus } \\
\hline Number of Bulletins & 21 \\
\hline Types & 2,002 \\
Tokens & 81,488 \\
Types/Token ratio $^{1}$ & 0.2445 \\
\hline
\end{tabular}

These bulletins are sent weekly to Greenpeace members and are a digest of what Greenpeace considers the most important news related to the green cause in Brazil. They bring a set of headlines, each of which is detailed by a small summary of a larger piece of news. The entire news can then be read by clicking on a hyperlink, usually displayed at the end of each paragraph and under the name leia mais (further reading) or saiba mais (learn more). The use of visuals is something common, since each topic is illustrated by an image, which represents either the people or the places that the news is about. The first word in the text is the word Olá (Hi!), which is a rather informal greeting in Brazil.

The typeface used is a non-serif font, probably Verdana, and titles and links have some typographic effect: links are underlined and titles are in bold. Most of the writing is done in black; exceptions are the name of Greenpeace, the date as well as the Copyright information, all written in white over a green background, with the word boletim (bulletin) in yellow. Green is the only colour used on the rounded frame that surrounds the text and in the bulletin titles. In the last third of theses bulletins is a table with hyperlinks that lead to webpages regarding affiliation, donation or new member recruitment. The contact information brings a request for members to call or write to Greenpeace to update their contact information. All this is presented in simple html format, no java or flash plugins.

Besides SFL, this research relies on the theoretical and methodological tools provided by Corpus Linguistics. This choice was made because this approach makes it possible to work with larger quantities of texts in a faster and more efficient way. In this approach, analysts carry out their research based on the collection and analysis of large amounts of linguistic data, which we call Corpus (BERBER SARDINHA, 2000). The different Corpuses (or

\footnotetext{
${ }^{1}$ Token/type ratio is a way of measuring lexical density; it is the number of unique words (types) divided by total number of word occurrences (tokens).
} 
Corpora) might be used for a number of different purposes, such as semantic analysis, syntax, language learning, design of pedagogical materials, among many other applications (BIBER et al., 1999; KENNEDY, 1998; MCENERY \& WILSON, 1996; SINCLAIR, 1991).

Leech (1991, p. 12) points out that concordancers (the analytical tool I use in this article) are very good at eliciting discrete elements, such as words and expressions. It means that they are not very efficient at distinguishing, for example, between $I$ (roman numeral) and $I$ (personal pronoun). Leech (1991, p. 12) suggests that this problem might be solved by the use of annotated corpora, which allows the analyst to retrieve the information built into the corpus. The limitation and solution observed by Leech are pertinent to this work, because process classification depends highly on the context as well as the analyst's background. Therefore, a tagging system based on letters and numbers was used. This system has already been used in two other studies (LIMA-LOPES, 2001, 2005b) and evaluated in Lima-Lopes (2005a). Each code is unique and identifies each element of the Transitivity System in the clause. Example 1 illustrates how these tags were administrated in the corpus: Greenpeace represents the Actor in the material process; presenteou (presented) is a material process; na uiltima terça-feira (last Tuesday) is a circumstance of location (time); and o presidente russo, Vladimir Putin (the Russian president...) is the recipient. ${ }^{2}$

(ex 1) Greenpeace $<$ trt10 > presenteou $<$ proc $100>$ na última Terça-feira $<\operatorname{circ} 22>$ o presidente russo, Vladimir Putin $<\operatorname{trt} 20>$

In this study I used WordSmith Tools (version 3.0), which is a software for lexical analysis. It is a commercial suite developed by Mike Scott (SCOTT, 1999), which performs a number of functions, such as concordance, word lists, keyword lists, consistency lists, etc. Here I used the concordance software in order to retrieve the tags referent to each transitivity element: instead of searching for words, the software searched for the codes, as in ex.1. It allows the researcher to make a systematic comparison among all the occurrences of a process, participant or circumstance, also observing which tags collocate more commonly.

\footnotetext{
${ }^{2}$ Due to limitations of space, a full list of tags would be rather long for such a short article. As such, I would like to invite the reader to consult to Lima-Lopes (2005a) for a complete list of this system.
} 
This method has been used in a number of SFL studies, such as Shimazumi (1996), who works with transitivity in a doctor/patient interaction; Wyatt (1997), who studies the interaction in e-mails; Feitosa (2005), who developed a tag system that can be used in a number of SFL areas; and Rodrigues Junior (2006), who compares transitivity in American gay short stories published during the 60's and their translations into Portuguese.

All the propositions used in this research are written in Brazilian Portuguese, but an English translation is offered after each Portuguese clause. It is important to bear in mind that an exact translation from the Brazilian Portuguese structures into English is rather difficult. To deal with these issues, in this paper, the translation was adapted so that it would sound closer to the source language - "as Brazilian as possible" - even though it might, at times, bring some uneasiness when reading. However, each time the "Englishness" of these examples is lost, a footnote with syntactic and semantic explanations is provided.

\section{Results}

These electronic bulletins seem to do much more than simply inform members about Greenpeace's achievements on behalf of the green cause; they actually show a very complex system of relations. Hence, Transitivity choices presented in these documents are not randon, but rather create a pattern of meanings which projects to each participant a specific role in the world represented by Greenpeace in these texts. These roles seem to be motivated by the communicational purpose, which not only makes some propaganda about Greenpeace's political agenda, but also influences people to become Greenpeace's affiliates or encourages them to donate money. The results are organized according to the participant that was studied: first the addressee; then Greenpeace; followed by activists, natural disasters and the government.

\subsection{The addressee}

In material processes, the addressee appears on propositions which instantiate demands for his/her participation, examples 2 and 3 . These processes are usually in imperative mode, and are related to the steps that the affiliate must take to participate in Greenpeace actions. 


\begin{tabular}{|l|c|c|c|c|c|}
\hline \multirow{3}{*}{$(2)$} & Clique & aqui & $\mathrm{e}$ & envie & sua mensagem de protesto \\
\cline { 2 - 6 } & Click & here & and & send & yourprotest message \\
\cline { 2 - 6 } & $\begin{array}{c}\text { Process: } \\
\text { Material }\end{array}$ & $\begin{array}{c}\text { Circumstance: } \\
\text { Place }\end{array}$ & & $\begin{array}{c}\text { Process: } \\
\text { Material }\end{array}$ & Participant: goal \\
\hline
\end{tabular}

\begin{tabular}{|l|c|c|c|}
\hline \multirow{3}{*}{$(3)$} & ...retire & dos supermercados & os produtos transgênicos sem rótulo \\
\cline { 2 - 4 } & ...take away & from the supermarkets & the Genetically Modified products with no label \\
\cline { 2 - 4 } & Process: & Participant: & Participant: goal \\
& Material & Recipient & \\
\hline
\end{tabular}

In other propositions, the addressee is requested to establish some sort of contact with Greenpeace. This contact might take place by updating the personal contact information, such as calling Greenpeace's office directly (examples 4/5); asking him/her to visit its website (example 6); or by requesting him/her to take notes about a new Greenpeace address (example 7). In example 4, the demand for contact is instantiated in a projected clause, preceded by a verbal proposition, which may be considered a politeness strategy: in Brazilian Portuguese, a direct demand for information might sound rather rude if not introduced accordingly. In example 6, the demand is a way to make the addressee access the organisation's website, here instantiating a full scope, a role also actualised by the company address in example 7.

\begin{tabular}{|c|c|c|c|c|c|c|}
\hline (4) & Pedimos que & você & atualize & seus dados & pelo telefone \\
\cline { 2 - 7 } & $(W e)$ & Ask & you & to update & your data & by telephone \\
\cline { 2 - 7 } & $\begin{array}{c}\text { Participant: } \\
\text { Sayer }\end{array}$ & $\begin{array}{c}\text { Process: } \\
\text { Verbal }\end{array}$ & $\begin{array}{c}\text { Participant: } \\
\text { Actor }\end{array}$ & $\begin{array}{c}\text { Process: } \\
\text { Material }\end{array}$ & $\begin{array}{c}\text { Participant: } \\
\text { Goal }\end{array}$ & $\begin{array}{c}\text { Circumstance: } \\
\text { Mode }\end{array}$ \\
\cline { 2 - 7 } & \multicolumn{4}{|c|}{ Projecting Clause } & \multicolumn{4}{|c|}{ Projed Clause } \\
\hline
\end{tabular}

\begin{tabular}{|l|c|c|c|}
\hline \multirow{3}{*}{$(5)$} & Entre & em contato $^{4}$ & com PERSON-A, assessora de imprensa \\
\cline { 2 - 4 } & \multicolumn{2}{|c|}{ Contact } & PERSON-A, our PR. \\
\cline { 2 - 4 } & $\begin{array}{l}\text { Process: } \\
\text { Material }\end{array}$ & $\begin{array}{c}\text { Participant: } \\
\text { Scope }\end{array}$ & Participant: Recipient \\
\hline
\end{tabular}

${ }^{3}$ Please, see discussion on example 11 for comparison and further analysis of example 3. ${ }^{4}$ In Portuguese Contact (Entre em contato) can be expressed both by a single verb (contatar) or by a verb followed by a scope, as in the example 5 . 


\begin{tabular}{|l|c|c|c|}
\hline (6) & Veja & mais dicas & em nosso site. \\
\cline { 2 - 4 } & See & more tips & in our website \\
\cline { 2 - 4 } & Process: Material & Participant: Scope & Circumstance: Place \\
\hline
\end{tabular}

\begin{tabular}{|l|l|c|c|}
\hline (7) & \multicolumn{2}{|c|}{ Anote $^{5}$} & nosso novo endereço \\
\cline { 2 - 4 } & Take & note & of our new address \\
\cline { 2 - 3 } & \multicolumn{2}{|c|}{ Process: Material } & Participant: scope \\
\hline
\end{tabular}

Verbal processes instantiate a very specific function in these bulletins: protest actions against what Greenpeace considers offensive to the green cause. In these processes, Greenpeace affiliates and local community members instantiate the Sayer role.

\begin{tabular}{|c|c|c|c|c|}
\hline (8) & $\begin{array}{c}\text { Moradores de comunidades } \\
\text { da região e o Greenpeace }\end{array}$ & protestaram & hoje & $\begin{array}{c}\text { contra o desmatamento } \\
\text { da Amazônia }\end{array}$ \\
\cline { 2 - 5 } & Community members and $G$. & protested & today & against the Amazon's deforestation \\
\hline Participant: Sayer & $\begin{array}{c}\text { Process: } \\
\text { verbal }\end{array}$ & $\begin{array}{c}\text { Circumstance: } \\
\text { Location Time }\end{array}$ & Participant: Target \\
\hline
\end{tabular}

Mental processes instantiate meanings in which Greenpeace offers information about the green cause. In example 9, he/she is the Senser in proportions about the political position of Brazilian Representatives. This example is also worth observing due to the fact that the Phenomenon is a projected clause, a very common construction in Brazilian Portuguese.

\begin{tabular}{|l|c|c|c|c|}
\hline (9) & Saiba & a posição & defendida & $\begin{array}{c}\text { pelos políticos em questôes } \\
\text { ambientais importantes }\end{array}$ \\
\cline { 3 - 5 } & & $\begin{array}{c}\text { the political position } \\
\text { Learn }^{6}\end{array}$ & kept & $\begin{array}{c}\text { by politicians regarding } \\
\text { important environmental issues }\end{array}$ \\
\cline { 2 - 5 } & Participant: Goal & $\begin{array}{c}\text { Process: } \\
\text { material }\end{array}$ & Participant: Actor \\
\hline & $\begin{array}{c}\text { Process: } \\
\text { Mental }\end{array}$ & \multicolumn{3}{|c|}{ Participant: Phenomenon } \\
\cline { 2 - 5 } $\begin{array}{c}\text { Embedding } \\
\text { clause }\end{array}$ & \multicolumn{3}{|c|}{ Embedded clause } \\
\hline
\end{tabular}

\footnotetext{
${ }^{5}$ In Portuguese, take note (anotar) can be expressed as a single verb.

${ }^{6}$ In Brazilian Portuguese, the use of Saber (learn/know) in imperative is something common.
} 
In other cases, example 10, the mental action is related to a number of feelings that the addressee is exposed to during some art exhibition promoted by Greenpeace.

\begin{tabular}{|c|c|c|l|c|}
\hline (10) & $\begin{array}{c}\text { Ao passar pela instalação, } \\
\text { de } 150 \mathrm{~m} 2,\end{array}$ & as pessoas & sentirão & $\begin{array}{c}\text { o vento dos tornados e a poluição } \\
\text { de escapamentos e chaminés }\end{array}$ \\
\cline { 2 - 5 } & $\begin{array}{c}\text { Passing by the } 150 \mathrm{~m}^{2} \\
\text { installation, }\end{array}$ & the people & will feel & $\begin{array}{c}\text { the wind of a tornado and the pollution } \\
\text { from exhausting pipes and chimneys }\end{array}$ \\
\cline { 2 - 5 } & $\begin{array}{c}\text { Circumstance: } \\
\text { Concomitance }\end{array}$ & $\begin{array}{c}\text { Participant: } \\
\text { Senser }\end{array}$ & $\begin{array}{c}\text { Mental } \\
\text { Process }\end{array}$ & Participant: Phenomenon \\
\hline
\end{tabular}

Requests for affiliation are also very common in these bulletins. Greenpeace tries to make every addressee join the organisation by becoming a monthly donor, as we see in 11 . In this example, both a Material process, which defines the relation of Greenpeace with companies or governments, and a Relational process, that explains the importance of each personal contribution, precede the material action of affiliation. That seems to function as a way to reinforce the importance of the participation of each individual and, at the same time, brings to the knowledge of the reader one of the main characteristics of Greenpeace, being independent.

\begin{tabular}{|c|c|c|c|c|c|}
\hline (11) & O Greenpeace & não aceita & dinheiro & \multicolumn{2}{|c|}{ de empresas ou governos } \\
\cline { 2 - 7 } & Greenpeace & does not take & money & \multicolumn{2}{|c|}{ from companies or governments } \\
\cline { 2 - 7 } & $\begin{array}{c}\text { Participant: } \\
\text { Actor }\end{array}$ & $\begin{array}{c}\text { Process: } \\
\text { Material }\end{array}$ & $\begin{array}{c}\text { Participant: } \\
\text { Goal }\end{array}$ & \multicolumn{2}{|c|}{ Circumstance: Origin } \\
\hline Por isso & sua contribuição & é & fundamental & para nosso trabalho \\
\hline So, & your contribution & is & critical & \multicolumn{2}{|c|}{ to our work } \\
\hline & $\begin{array}{c}\text { Participant: } \\
\text { Carrier }\end{array}$ & Process: & Pelational & $\begin{array}{c}\text { Participant: } \\
\text { Attribute }\end{array}$ & \multicolumn{2}{|c|}{$\begin{array}{c}\text { Circumstance: } \\
\text { Behalf }\end{array}$} \\
\hline & aqui & e & filie-se & já & ao Greenpeace \\
\hline Clique & here & and & Join & now & Greenpeace \\
\hline Click & Participant: & & Process: & & Participant: \\
Scope & & Material & & Recipient \\
\hline
\end{tabular}

Example 11 brings a recurrent function in these bulletins: a wording that introduces participants in an indirect way by means of a circumstance resembling some functions of a process (HALLIDAY, 1994). Example 11 is an instance of Greenpeace as an Actor in a material process, which prepares the scene for a demand of individual contribution. Since Greenpeace does not take any assistance from such entities, individual support is essential for its 
maintenance and such a wording seems critical to set the relationship between Greenpeace companies and governments (introduced in a circumstance). In the next proposition; as the contribution is characterised as of importance, the circumstance para nosso trabalho (to our work) establishes a reference to Greenpeace's actions on behalf of the green cause and, indirectly, makes Greenpeace a recipient of possible donations. In grammatical terms, this indirect participant role performed by para nosso trabalho allows an Actor/ Receiver function to be actualised in a relational clause. The actual demand is introduced in the next proposition. Clique (click) $e$ (and) filie-se (join) is a material process in an imperative mode, in which the reader is the Actor and Greenpeace a direct Recipient. It is importance to observe that, although it is not expressed in 11, the act of affiliation demands a monthly contribution.

It is also worth comparing de empresas ou governos (from companies or governments), example 11, to dos supermercados (from the supermarkets), example 3, due to the fact that both have very similar wording but slightly contrasting functions. Although both arguments are connected to the process by the same preposition, deldo (form), ${ }^{7}$ in example 3, the supermarkets are going to be deprived of their products (which play the Goal) if they are taken away from the shelves. The supermarkets would be receiving some action done by those activists - thus, the clause would clearly denote a transfer of the possession of goods (HALLIDAY \& MATTHIESSEN, 2004, p. 191) if the activists followed Greenpeace's orders. Since this would bring some beneficiary meaning to supermercados, it is worth observing that once a participant is portrayed as a Client or Recipient, the benefit it receives might not actually be beneficial; it merely indicates some intervention over the participant (HALLIDAY, 1994, p. 145). De empresas ou governos, on the other hand, are not affected by Greenpeace's actions; they represent a model of sponsorship, thus donating on free will. As it seems, de empresas ou governos introduces a participant with traces of an Actor: the companies might donate, but Greenpeace would rather not accept their money (here playing the Goal) ${ }^{8}$

${ }^{7}$ In Portuguese (both Brazilian and European), the preposition de (meaning both "from" or "of") can be used together with the articles "o", male, or "a", female (meaning "the"), in a contracted form: $\mathrm{de}+\mathrm{O}=\mathrm{do}$ and $\mathrm{de}+\mathrm{a}=\mathrm{da}$ (from the or of the). ${ }^{8}$ These differences might be more evident if we probe the processes and circumstances in such propositions; as suggested by Halliday (1994, p. 110-11, 152-153, 165-166). In the propositions studied, both dos supermercados and de empresas e governos would be probed for Where from?, which would characterise 
Relational Processes can be used to put the reader under pressure. It happens in some headings demanding a straight ideological position from the reader (example 12).

\begin{tabular}{|c|c|c|c|c|}
\hline (12) & Armas: & de que lado & você & está? \\
\cline { 2 - 5 } & Weapons: & on which side & you (singular) & are? \\
\cline { 2 - 5 } & & $\begin{array}{c}\text { Circumstance: } \\
\text { location: place }\end{array}$ & $\begin{array}{c}\text { Participant: } \\
\text { Carrier }\end{array}$ & $\begin{array}{c}\text { Process: Relational } \\
\text { attributive }\end{array}$ \\
\hline
\end{tabular}

The main difference in meaning between the propositions instantiated in 11 and 12 is the kind of demand that is made. In the former, the reader is represented by something $s /$ he is capable of doing; the importance of the reader relies on this. In the latter, the demand is a straight question that is a reference to the Brazilian recent history: a referendum in which people should vote for or against the prohibition of firearms in Brazil.

In some other clauses, the addressee is also asked to take actions on behalf of the environment. As we can see in example 13, these actions have the addressee as the Actor and mostly instantiate actions concerning the acquisition of products that are certified or generally accepted by Greenpeace. In this example, one might also notice that a circumstance of mode has the function of diminishing the power of this demand.

\begin{tabular}{|l|c|c|c|}
\hline \multirow{3}{*}{$(13)$} & Sempre que possível, & compre & alimentos orgânicos... \\
\cline { 2 - 4 } & Whenever possible & buy & organic food... \\
\cline { 2 - 4 } & Circumstance: Mode & Process: Material & Participant: Goal \\
\hline
\end{tabular}

In some propositions, the addressee is represented as someone who is invited to take part in some of Greenpeace's activities and campaigns, a

both as Circumstances of Origin. Both Retire in 3 (take way from) and aceitar (accept) in 11 can be easily probed in the passive voice. In 11, we are assuming the reader as an Actor in the original proposition: Os produtos (...) são retirados dos supermercados por você (The products (...) will be taken away from the supermarkets by you); while, in the second, Greenpeace is clearly the Actor: $\mathrm{O}$ dinheiro de empresas e governos não é aceito pelo Greenpeace (The money from companies or governments is not accepted by Greenpeace). Retire in 3 (take way from) can easily be probed for confisque (confiscate), which would result in a very similar wording, Confisque dos supermercados os produtos transgênicos sem rótulo. In the same way, aceitar (accept) could be probed for receber (receive), and the grammatical result would be very similar as well: O Greenpeace não recebe dinheiro de empresas ou governos. 
position that is instantiated by the addressee as a Carrier in Relational Attributive processes.

\begin{tabular}{|c|c|c|c|c|c|}
\hline (14) & O Greenpeace & realizará & $\begin{array}{c}\text { no Shopping } \\
\text { Frei Caneca }\end{array}$ & atividades & $\begin{array}{c}\text { para comemorar a Semana } \\
\text { do Meio Ambiente }\end{array}$ \\
\cline { 2 - 4 } Greenpeace & will promote & $\begin{array}{c}\text { at the Frei Caneca } \\
\text { Shopping Centre }\end{array}$ & activities & $\begin{array}{c}\text { to celebrate the } \\
\text { environmental week }\end{array}$ \\
\hline $\begin{array}{c}\text { Participant: } \\
\text { Actor }\end{array}$ & $\begin{array}{c}\text { Process: } \\
\text { Material }\end{array}$ & $\begin{array}{c}\text { Circumstance: } \\
\text { Location: time }\end{array}$ & $\begin{array}{c}\text { Participant: } \\
\text { Goal }\end{array}$ & Circumstance: Purpose \\
\hline Você & $\mathrm{e}^{9}$ & nosso convidado & & \\
\cline { 2 - 4 } You (singular) & are & our guest & \\
\cline { 2 - 4 } & $\begin{array}{c}\text { Participant: } \\
\text { Carrier }\end{array}$ & $\begin{array}{c}\text { Process: } \\
\text { Relational }\end{array}$ & $\begin{array}{c}\text { Participant: } \\
\text { Attribute }\end{array}$ & \\
\end{tabular}

These processes operate similarly to examples 2 and 3 , in which Greenpeace tries to bring the reader to participate in the campaign. The difference relies on the grammatical choices, though. Material processes are frequently in the imperative mode; this might be understood as a direct intervention on reader's behaviour. On the other hand, the relational processes are much less direct and sound like an invitation to a social event.

\begin{tabular}{|l|c|c|}
\hline (15) & Assista & ao filme "Amazon Place" \\
\cline { 2 - 3 } & Watch & the movie "Amazon Place" \\
\cline { 2 - 3 } & Process: Behavioural & Participant: Behaviour \\
\hline
\end{tabular}

Behavioural processes actualise imperative propositions, always related to attempts to make the addressee get in contact with videos promoted by Greenpeace. As we can see in example 15, the addressee represents the Behaver, which is not explicit in the sentence, whilst the video/film always instantiates the Behaviour.

The addressee, the person who these bulletins are addressed to, is the participant to whom the largest number of functions is ascribed. This might be because this participant is critical to the existence of Greenpeace; he/she is the person that supports this organisation. As we can see in the following picture, each of the functions I discussed above seems to be related to a specific wording.

${ }^{9}$ In Portuguese, the verb to be is represented by two verbs: ser and estar. Ser is identified as a non-transitory and permansive aspect, and is thus related to actions that tend to last, such as Eu sou causasiano (I'm caucasian); on the other hand, Estar is related to a more transitory aspect, and would occur in sentences like: Ele não está em casa (He is not at home). 


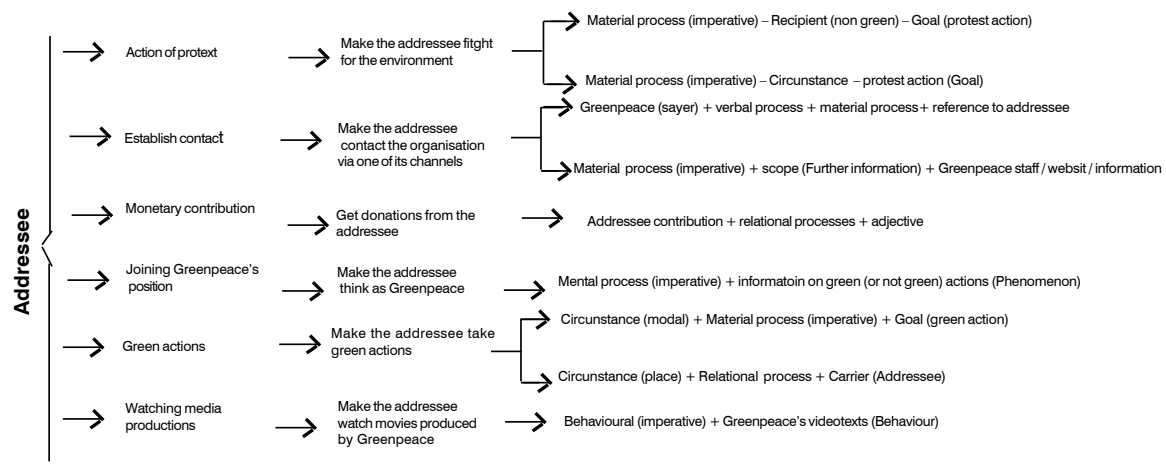

PICTURE 1: Functions by the addressee

This seems to show that the choices in terms of transitivity are not random. Each wording is responsible for encoding a certain social meaning in the discourse regarding one of the participants present in such documents. Greenpeace is the second participant that instantiates the larger number of functions, as picture 2 shows. It is important to note that there are two kinds of functions: 1) related to institutional propaganda and 2) related to the attempts to gain affiliates. As we can see in the picture above, each of the functions performed by the addressee is represented by very specific choices within the system of transitivity. There is a clear identification between the function performed by the participant and such patterns. For example, the actions of protest are instantiated only by material processes, necessarily in the imperative Mood. In this context, "protest actions" and "non-green" individuals represent the goals and scopes, respectively. The contact demands also work with very clear patterns: they are directed to the recipient and project materials clauses. In the recipient's roles there is a relationship between the instantiated patterns and the political position that Greenpeace would like them to take.

\subsection{Greenpeace}

Greenpeace is the Actor in a number of material processes, which have rather different functions. There are some propositions that show to the reader which steps are being taken towards the green cause, such as in 16 and 17. Example 17 is important, because, Amazonia, which is grammatically representing the origin of the wood, is the very region of Brazil Greenpeace wants to preserve. Amazonia is affected by such actions and might feel as a participant to the reader, in a strategy that is quite similar to that used in examples 11 and 3. However, by telling the reader that Amazonia is a source of illegal wood, Greenpeace is trying to make an ideological statement by showing the reader it is fighting for one of Brazil's national assets. 


\begin{tabular}{|c|c|c|c|c|}
\hline \multirow[t]{3}{*}{ (16) } & Greenpeace & lançou & nesta quarta-feira $(23 / 8)$ & $\begin{array}{c}\text { o documentário } \\
\text { "Mudanças do clima..." }\end{array}$ \\
\hline & Greenpeace & launched & this Wednesday & $\begin{array}{l}\text { the documentary: } \\
\text { "Mudanças do..." }\end{array}$ \\
\hline & $\begin{array}{c}\text { Participant: } \\
\text { Actor }\end{array}$ & $\begin{array}{l}\text { Process: } \\
\text { Material }\end{array}$ & Circumstance: Time & Participant: Goal \\
\hline
\end{tabular}

\begin{tabular}{|c|c|c|c|c|}
\hline (17) & Greenpeace & compra & carregamento de madeira ilegal & na amazônia. \\
\cline { 2 - 5 } & Greenpeace & buys & illegal woodshipment & in the Amazon \\
\cline { 2 - 5 } & $\begin{array}{c}\text { Participant: } \\
\text { Actor }\end{array}$ & $\begin{array}{c}\text { Process: } \\
\text { Material }\end{array}$ & Participant: Goal & $\begin{array}{c}\text { Circumstance: } \\
\text { Place }\end{array}$ \\
\hline
\end{tabular}

Some of these actions might involve a specific relationship with governments and their members. In this case, they are always the addressee of documents or things that symbolise, to some extent, Greenpeace's fight on behalf of the environment. As we see in example 18, the circumstance na sede da Polícia Federal (at Federal Police headquarters) also seems to introduce a participant; although it is telling the reader the place where the shipment was delivered, Greenpeace is trying to involve the police within the action as an indirect Recipient.

\begin{tabular}{|c|c|c|}
\hline (18) & Na manhã desta segunda-feira, 19 de dezembro, & ativistas do Greenpeace \\
\cline { 2 - 3 } & In the morning of this Monday, December 19 $9^{\text {th }}$ & Greenpeacés activists \\
\hline Circumstance Location: time & Participant: Actor \\
\hline entregaram & $\begin{array}{c}\text { o carregamento de madeira } \\
\text { amazônica ilegal }\end{array}$ \\
\hline delivered & the shipment of illegal Amazon wood \\
\hline Process: Material & Participant: Goal \\
\hline na sede da Polícia Federal & em São Paulo \\
\hline to the headquarters of the Federal Police & in São Paulo \\
\hline Circumstance: place & Circumstance of location: place \\
\hline
\end{tabular}

Greenpeace also tries to show that its activities go beyond what is traditionally published by the media; an example would be its work in humanitarian aid. In the corpus, this function is realised by circumstances of place (in Lebanon, ex. 19), which is introducing the country or region that is receiving the aid. Such a wording might be due to the process choice in Portuguese: literally translating, the writer has chosen to use collaborate (colaborar), which does not take a second argument. It shows that some grammatical choices within the Transitivity System are conditioned not only by the meaning represented, but also by some grammatical features of each language. 


\begin{tabular}{|c|c|c|c|c|}
\hline (19) & Greenpeace & colabora com & ajuda humanitária & no Líbano. \\
\cline { 2 - 5 } & Greenpeace & collaborates with & humanitarian aid & in Lebanon \\
\cline { 2 - 5 } & Participant: Actor & Process: Material & Participant: Goal & Circumstance: Place \\
\hline
\end{tabular}

Sometimes the name of Greenpeace is not present, but it might be retrieved from the context. In these propositions there is a nominal group, which is usually one of Greenpeace's actions or campaigns. Example 20 is a typical instantiation of this meaning: there is an initial clause where the action or campaign is the Actor, followed by a projected clause that brings the details on what Greenpeace has done.

\begin{tabular}{|c|c|c|c|c|c|c|}
\hline (20) & A investigação & mostra & como & a soja amazônica & vai parar & $\begin{array}{c}\text { nas prateleiras de } \\
\text { supermercados }\end{array}$ \\
\cline { 2 - 7 } & The investigation & shows & how & Amazon soybeans & end up & on supermarket shelves \\
\hline & $\begin{array}{c}\text { Participant: } \\
\text { Sayer }\end{array}$ & $\begin{array}{c}\text { Process: } \\
\text { Verbal }\end{array}$ & & $\begin{array}{c}\text { Participant: } \\
\text { Actor }\end{array}$ & $\begin{array}{c}\text { Process: } \\
\text { Material }\end{array}$ & $\begin{array}{c}\text { Circumstance: } \\
\text { Place }\end{array}$ \\
\hline \multicolumn{2}{|c|}{ Projecting Sentence } & \multicolumn{4}{|c|}{ Circumstance: Mode } \\
\cline { 2 - 6 } & \multicolumn{4}{|c|}{ Projected Sentence } \\
\cline { 3 - 6 }
\end{tabular}

In this projected clause, example 20, the participants are instantiated by different entities. This structure seems to be used as a way to introduce a greater deal of detail about Greenpeace's work, shifting the focus of its own name to its actions. Another way of actualising Greenpeace is through its activists, as we can see in examples 21 and 22. Here the focus is on the person who takes part in these campaigns, probably a means of showing people how they can help Greenpeace in its actions.

This may include another sort of action: political pressure over governments (see example 22). In these propositions, activists always deliver documents whose recipient is the government, as discussed earlier.

\begin{tabular}{|c|c|c|c|c|c|}
\hline (21) & Em 11 países, & ativistas & realizaram & ato simbólico & em defesa da Amazônia \\
\cline { 2 - 6 } & In 11 countries, & activists & promoted & a symbolic protest & on behalf of the Amazon \\
\cline { 2 - 6 } & Circumstance: & Participant: & Process: & Participant: & Circumstance: Behalf \\
& Place & Actor & Material & Goal & \\
\hline
\end{tabular}

\begin{tabular}{|c|c|c|c|c|c|c|}
\hline (22) & Ativistas & entregaram & dossiê & ao governo & $\begin{array}{c}\text { durante } \\
\text { manifestação }\end{array}$ & em Brasília \\
\cline { 2 - 7 } & Activists & handed in & a dossier & $\begin{array}{c}\text { to the } \\
\text { government }\end{array}$ & during the protest & in Brasilia \\
\cline { 2 - 7 } & $\begin{array}{c}\text { Participant: } \\
\text { Actor }\end{array}$ & $\begin{array}{c}\text { Process: } \\
\text { Material }\end{array}$ & $\begin{array}{c}\text { Participant: } \\
\text { Goal }\end{array}$ & $\begin{array}{c}\text { Participant: } \\
\text { Recipient }\end{array}$ & $\begin{array}{c}\text { Circumstance: } \\
\text { Location: Time }\end{array}$ & $\begin{array}{c}\text { Circumstance: } \\
\text { Location: Place }\end{array}$ \\
\hline
\end{tabular}


Processes like Protestar (to protest - example 23) are used to tell readers which actions Greenpeace is directly verbalising; protestar holds a nonconformist point of view, which is related to Greenpeace's original objective. It is fair to say that this choice is not random: here the organisation is portrayed as doing the job it is intended to and so honouring its affiliates' contributions. In functional terms, we can observe it has a Process-Target structure in which Greenpeace is commonly portrayed as the Sayer.

\begin{tabular}{|l|c|c|c|}
\hline (23) & O Greenpeace & protesta & contra o maior desmatamento dos últimos anos \\
\cline { 2 - 4 } & Greenpeace & protests & against the largest deforestation activity in recent years \\
\cline { 2 - 4 } & Participant: Sayer & Process: verbal & Participant: Target \\
\hline
\end{tabular}

As we can see in the three following examples, some propositions seem to explain either some of Greenpeace's characteristics or its objectives in its campaigns. As in example 24, the word expedition, which is a reference to a journey of Greenpeace's ship along the Brazilian coast, is the participant identified in the clause. This identification makes a clear statement about what such an expedition is doing.

\begin{tabular}{|c|c|c|c|c|}
\hline \multirow[t]{9}{*}{ (24) } & $\begin{array}{c}\text { O objetivo } \\
\text { da expedição, }{ }^{10}\end{array}$ & que & é & $\begin{array}{l}\text { parte da campanha global } \\
\text { pela proteção das florestas, }\end{array}$ \\
\hline & $\begin{array}{l}\text { The aim of this } \\
\text { expedition }\end{array}$ & which & is & $\begin{array}{c}\text { part of a global campaign to } \\
\text { protect the forests, }\end{array}$ \\
\hline & $\begin{array}{l}\text { Participant: } \\
\text { Identified }\end{array}$ & $\begin{array}{l}\text { Participant: } \\
\text { Carrier }\end{array}$ & $\begin{array}{l}\text { Process: Relational } \\
\text { attributive }\end{array}$ & Participant: Attribute \\
\hline & $\begin{array}{c}\text { Embedding clause } \\
\text { (Clause-1) }\end{array}$ & \multicolumn{3}{|c|}{$\begin{array}{c}\text { Embedded clause (clause-2) } \\
\text { (Clause } 1 \text { is interrupted) }\end{array}$} \\
\hline & é & levar & $\begin{array}{l}\text { a realidade de regiōes } \\
\text { remotas da Amazônia }\end{array}$ & $\begin{array}{c}\text { para os grandes centros } \\
\text { urbanos }\end{array}$ \\
\hline & \multirow[t]{2}{*}{ is } & to take & $\begin{array}{l}\text { the reality of remote } \\
\text { regions of the Amazon }\end{array}$ & to the large urban centres \\
\hline & & \multicolumn{3}{|c|}{ Participant: Identifier } \\
\hline & $\begin{array}{l}\text { Process: Relational } \\
\text { Identificative }\end{array}$ & $\begin{array}{l}\text { Process: } \\
\text { Material }\end{array}$ & Participant: Goal & Participant: Recipient \\
\hline & $\begin{array}{l}\text { Embedding clause } \\
\text { (Clause-1)-Retaken }\end{array}$ & \multicolumn{3}{|c|}{ Embedded clause (Clause-3) } \\
\hline
\end{tabular}

${ }^{10}$ In Brazilian Portuguese, the use of embedded clauses is very usual in written genres. I creates some long clauses complexes in which the main sentence, most of the time, is temporally interrupted. Example 24 is an instance of such use: $\mathbf{O}$ objetivo da expedição, que é parte da campanha global pela proteção das florestas, é levar a 
This is also true in propositions like 25, which shows the extension of a campaign. Here it is a carrier of a relational attributive process, usually in an embedded clause. In this clause complex, Greenpeace is defined twice: 1) one that tells how far Greenpeace's work can go and 2) another concerning the objective of the campaign.

\begin{tabular}{|c|c|c|c|c|c|}
\hline \multirow[t]{9}{*}{$(25)$} & A expedição & que & esteve & em oito cidades & promoveu \\
\hline & The expedition & which & was & in eight cities & promoted \\
\hline & $\begin{array}{l}\text { Embedding } \\
\text { sentence }\end{array}$ & $\begin{array}{l}\text { Participant: } \\
\text { Carrier }\end{array}$ & $\begin{array}{c}\text { Process: } \\
\text { Relational } \\
\text { attributive }\end{array}$ & $\begin{array}{c}\text { Circumstance: } \\
\text { Extension: } \\
\text { Time }\end{array}$ & $\begin{array}{l}\text { Process: } \\
\text { Material }\end{array}$ \\
\hline & & \multicolumn{3}{|c|}{ Embedded sentence } & $\begin{array}{c}\text { Embedding } \\
\text { sentence }\end{array}$ \\
\hline & \multicolumn{5}{|l|}{$\begin{array}{l}\text { Participant: } \\
\text { Actor }\end{array}$} \\
\hline & \multicolumn{2}{|c|}{ propostas para } & \multicolumn{3}{|c|}{ a proteção da Floresta Amazônica. } \\
\hline & \multicolumn{2}{|c|}{ alternatives for } & \multicolumn{3}{|c|}{ the protection of the Amazon Forest } \\
\hline & \multicolumn{2}{|c|}{ Participant: Goal } & \multicolumn{3}{|c|}{ Participant: Client } \\
\hline & \multicolumn{5}{|c|}{ Embedding sentence } \\
\hline
\end{tabular}

The same political agenda is present in example 26, which demonstrates Greenpeace's sympathy to other causes, in this case a campaign against the US presence in Iraq. Example 27 brings a use of Relational processes that is very similar to that in the Material processes: to define Greenpeace as a non-profit organisation.

In examples 26 and 27, Greenpeace is not represented by its name but by the pronoun Nós [we]. According to Ramos (1997), who studies image projection in business, these choices represent different interpersonal meanings: the name of the organisation seems to be much more formal and distant, whilst the pronoun we is used as a way to define the company as a group formed by actual people. In fact, the results in this work are very similar to Ramos'; the use of We may be a way to get closer to the reader, including he/she in Greenpeace's actions. Ramos' work deals with documents written in English, a fact that is quite important to notice, since it makes this strategy something similar in both languages.

realidade de regiôes remotas da Amazônia para os grandes centros urbanos. The main clause is in bold, the first embedded clause is underlined, while the second embedded clause is italicised 


\begin{tabular}{|c|c|c|c|c|}
\hline (26) & Nós & estamos & muito felizes & por poder contribuir de alguma forma \\
\cline { 2 - 5 } & We & are & very happy & to be able to contribute in some way... \\
\cline { 2 - 5 } & $\begin{array}{c}\text { Participant: } \\
\text { Carrier }\end{array}$ & $\begin{array}{c}\text { Process: } \\
\text { Relational } \\
\text { attributive }\end{array}$ & $\begin{array}{c}\text { Participant: } \\
\text { Attribute }\end{array}$ & Circumstance: Purpose \\
& & \\
\hline
\end{tabular}

\begin{tabular}{|c|c|c|}
\hline$(27)$ & Somos & $\begin{array}{c}\text { uma organização financeiramente independente de empresas, } \\
\text { partidos políticos. . }\end{array}$ \\
\cline { 2 - 3 } & {$[$ We] are } & $\begin{array}{c}\text { an organisation financially independent of companies, political } \\
\text { parties. . . }\end{array}$ \\
\cline { 2 - 3 } & Participant: Carrier & Participant: Attribute \\
\hline
\end{tabular}

As shown in picture 2, Greenpeace also uses a complex system of representations of its functions, which results in some patterns of choice. When demanding personal information, Greenpeace is represented by the pronoun we. Firstly, Greenpeace reinforces the need to keep in touch with its affiliates, and then, in a projected sentence, introduces the actual request. This same pattern of demand is present in the use of we as a Sayer in verbal processes: a projected clause is that which is responsible for introducing the real demand. A similar structure is also present when some requests for donation take place. In a first moment, the addressee is told that Greenpeace does not take money from companies and relies only on individual donations. The actual request comes in a projected sentence.

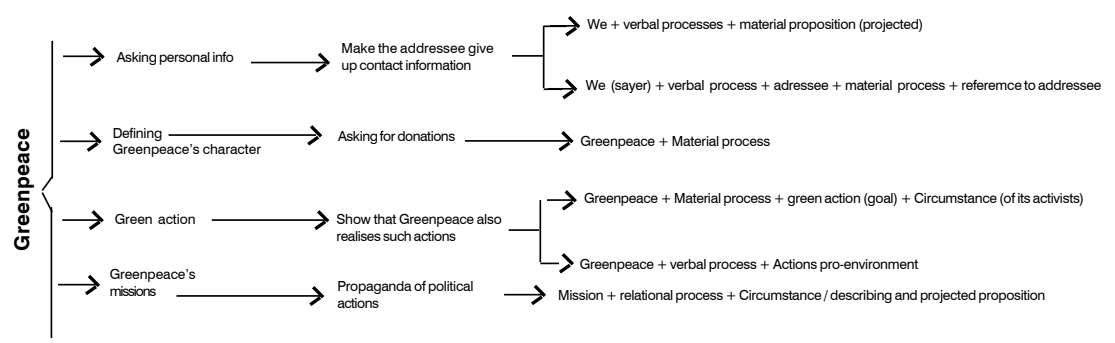

PICTURE 2: Functions performed by Greenpeace

\subsection{Other activists and natural disasters}

There is another kind of activist who also pops up in a number of propositions: people who do not belong to Greenpeace but whose actions are approved of by it (picture 3). 
An example of these activists is Sister Dorothy, an American nun who was killed in Brazil. As we can see in example 28, Sister Dorothy is treated as someone who has deep roots in the Transamasonica region, portrayed as a fighter for the rural communities' rights. This reflects an important pattern: these activists are actors in actions endorsed by Greenpeace.

These activists are also portrayed as victims of murder and other vicious actions (ex. 29). By causing a feeling of sorrow for those who were killed during the fight for the green cause, Greenpeace is trying to make the addressee aware of the sacrifice those people might be going through. Some grammatical features are very important to elucidate this strategy: as we see in the example 29, these activists might realise Recipients of material processes, which do not have a clear Actor. The green activists are clearly recognised as accountable for their pro-environmental actions, while the killers remain unidentified.

\begin{tabular}{|c|c|c|c|c|c|c|}
\hline \multirow[t]{12}{*}{$(28)$} & Irmã Dorothy & vivia & \multicolumn{2}{|c|}{ há mais de 30 anos } & \multicolumn{2}{|c|}{ na região da Transamazônica } \\
\hline & Sister Dorothy & lived & \multicolumn{2}{|c|}{ for over 30 years } & \multicolumn{2}{|c|}{ in the Transamasonica region } \\
\hline & $\begin{array}{l}\text { Participant: } \\
\text { Actor }\end{array}$ & $\begin{array}{l}\text { Process: } \\
\text { Material }\end{array}$ & \multicolumn{2}{|c|}{$\begin{array}{l}\text { Circumstance: } \\
\text { Duration: time }\end{array}$} & \multicolumn{2}{|c|}{$\begin{array}{c}\text { Circumstance: } \\
\text { Localisation: Place }\end{array}$} \\
\hline & \multirow[t]{2}{*}{ e } & \multirow[t]{2}{*}{ dedicou } & \multirow{2}{*}{\multicolumn{2}{|c|}{ quase metade de sua vida }} & para dar & voz \\
\hline & & & & & to give & voice \\
\hline & \multirow[t]{3}{*}{ and } & dedicated & \multicolumn{2}{|c|}{ almost half of her life } & Process: & Participant: \\
\hline & & Process: & \multirow{2}{*}{\multicolumn{2}{|c|}{$\begin{array}{l}\text { Circumstance: } \\
\text { Duration: time }\end{array}$}} & Material & scope \\
\hline & & Material & & & \multirow{2}{*}{\multicolumn{2}{|c|}{ Embedded clause (hypotaxis) }} \\
\hline & \multicolumn{4}{|c|}{ Parataxis } & & \\
\hline & \multicolumn{2}{|c|}{ às comunidades rurais $(\ldots)$} & & & & \\
\hline & \multicolumn{2}{|c|}{ to rural communities } & & & & \\
\hline & \multicolumn{2}{|c|}{ Participant: Recipient } & & & & \\
\hline \multirow[t]{4}{*}{$(29)$} & \multicolumn{2}{|c|}{ o sangue dos que } & lutam & \multicolumn{2}{|c|}{ pelo meio ambiente e por Justiça } & foi derramado \\
\hline & \multicolumn{2}{|c|}{ The blood of the ones who } & fight & \multicolumn{2}{|c|}{ for the environment and justice } & was spilt \\
\hline & \multicolumn{2}{|c|}{ Participant: Recipient } & $\begin{array}{l}\text { Process: } \\
\text { Material }\end{array}$ & \multicolumn{2}{|c|}{ Participant: Client } & \\
\hline & \multicolumn{5}{|c|}{ Participant: goal } & $\begin{array}{l}\text { Process: } \\
\text { Material }\end{array}$ \\
\hline
\end{tabular}

The natural disasters (picture 3) usually demonstrate that the Greenpeace's concerns about the planet are a serious matter. As one can see in example 30, these disasters usually play the role of Actors that do affect specific regions on Earth, in this case Brazil. These disasters are sometimes seen as a reaction that nature is taking against the action of men. 


\begin{tabular}{|c|c|c|c|c|}
\hline (30) & O aquecimento global & já & está afetando & o Brasil... \\
\cline { 2 - 5 } & Global warming & already & affects & Brazil \\
\cline { 2 - 5 } & Participant: Actor & $\begin{array}{c}\text { Circumstance: } \\
\text { Location: time }\end{array}$ & Process: Material & Participant: Goal \\
\hline
\end{tabular}

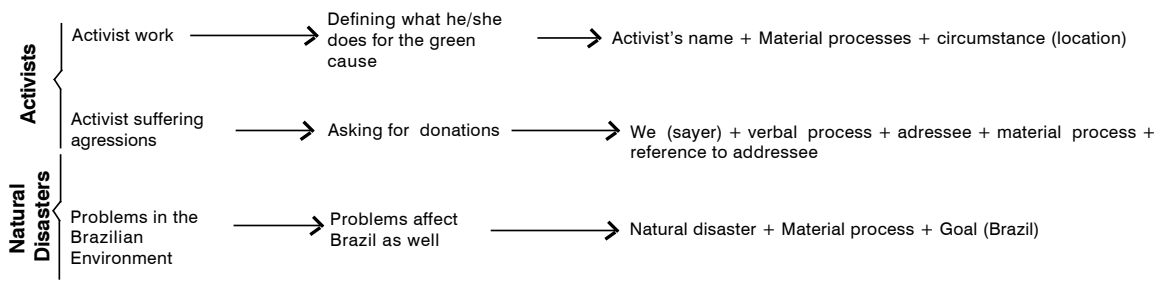

PICTURE 3: Functions of other activists and natural disasters

\subsection{Government}

Other participants, such as political actions/decisions, are also defined by Relational and Verbal processes (Picture 4). In these propositions, these actions/decisions are evaluated according to Greenpeace's view of their consequences to the green cause. As a result, it establishes a rather manicheist classification of such actions: pro or against the green cause. This is clear in examples 31 and 32: the former discusses the implementation of preservation areas on behalf of the rainforest in Brazil, something always seen as positive. The latter, on the other hand, evaluates a decision of the Brazilian Government, which started charging extra electricity fees in order to fund a nuclear project, something always negative in the view of Greenpeace.

\begin{tabular}{|c|c|c|c|c|}
\hline (31) & Entre essas medidas & constavam & $\begin{array}{c}\text { a criação de um mosaico } \\
\text { e unidades de conservação }\end{array}$ & na região da Terra do Meio \\
\cline { 2 - 5 } & Amongst these actions & [it] was present ${ }^{11}$ & $\begin{array}{c}\text { the creation of a number } \\
\text { of conservation areas }\end{array}$ & in the Terra do Meio region \\
\cline { 2 - 5 } & $\begin{array}{c}\text { Circumstance: } \\
\text { Location: Place }\end{array}$ & $\begin{array}{c}\text { Process: } \\
\text { Relational } \\
\text { attributive }\end{array}$ & Participant: Carrier & $\begin{array}{c}\text { Circumstance: Location: } \\
\text { Place }\end{array}$ \\
\hline
\end{tabular}

${ }^{11}$ Constar (infinitive form of constavam) does not have a straight translation into English. A possible translation would be: be composed by/be constituted of, be included in, be present in/at. Further reference can be found at the Houaiss Dictionary of Portuguese Language at http://houaiss.uol.com.br/busca.jhtm. 


\begin{tabular}{|c|c|c|c|c|}
\hline \multirow[t]{12}{*}{$(32)$} & Esta & foi & uma decisão & tomada \\
\hline & This & was & \multirow[b]{2}{*}{ a decision } & taken \\
\hline & \multirow[t]{3}{*}{$\begin{array}{l}\text { Participant: } \\
\text { Carrier }\end{array}$} & \multirow[t]{3}{*}{$\begin{array}{c}\text { Process: Relational } \\
\text { attributive }\end{array}$} & & $\begin{array}{l}\text { Circumstance: } \\
\text { Location: Place }\end{array}$ \\
\hline & & & Participant: Goal & Process: material \\
\hline & & & \multicolumn{2}{|c|}{ Participant: Attribute } \\
\hline & \multicolumn{2}{|c|}{ Embedding Clause } & \multicolumn{2}{|c|}{ Embedded Clause } \\
\hline & em surdina & $\begin{array}{l}\text { e sem a menor participação } \\
\text { da sociedade brasileira }\end{array}$ & & \\
\hline & without telling a soul & \multirow{2}{*}{$\begin{array}{c}\text { and without the participation } \\
\text { of the Brazilian society }\end{array}$} & & \\
\hline & & & & \\
\hline & $\begin{array}{l}\text { Circumstance: } \\
\text { manner: quality }\end{array}$ & $\begin{array}{c}\text { Circumstance: } \\
\text { contingency: default }\end{array}$ & & \\
\hline & \multicolumn{2}{|c|}{ Participant: Attribute } & & \\
\hline & \multicolumn{2}{|c|}{ Embedded Clause } & & \\
\hline
\end{tabular}

Example 31 brings an evaluation that is much less open and much more inscribed than in example 32. This difference in the evaluation brings some difference in the structure that is used in the propositions. In both, the decision takes the role of carrier; however, 31 is a circumstantial attributive process, which only tells us the location of the areas of conservation. Nevertheless, the circumstances in the attribute (example 32) are full of expressions, which, in Portuguese, sound rather aggressive and evoke a lack of transparency or even honesty.

Governments and their institutions always actualise the Sayers in verbal processes. These are announcements of different official actions, all of which consistently referent to positive results for the environment.

\begin{tabular}{|c|c|c|c|}
\hline (33) & O governo federal & anunciou & um pacote de medidas \\
\cline { 2 - 4 } & The federal government & announced & a number of actions \\
\cline { 2 - 4 } & Participant: Sayer & Process: verbal & Participant: Verbiage \\
\hline
\end{tabular}

The verbal process usually related to the government (example 33), such as anunciar (announce), sounds as if common verbal activities associated with a governmental spokesmen. As a result, these actions are portrayed in a much neutral proposition, very differently if compared to other governmental actions. 


\begin{tabular}{|c|c|c|c|}
\hline \multirow{10}{*}{ (34) } & Apesar de & muita gente & achar que \\
\cline { 2 - 4 } & Despite the fact that & lots of people & think that \\
\cline { 2 - 4 } & Participant: Senser & Process: Mental \\
\hline & \multicolumn{3}{|c|}{ Projecting Clause } \\
\hline aquecimento global & é & coisa de cinema \\
\hline global warming & is & movie stuff \\
\hline Participant: Carrier & $\begin{array}{c}\text { Process: relational } \\
\text { Attributive } \\
\end{array}$ & Projected Clause \\
\hline
\end{tabular}

\begin{tabular}{|l|c|c|c|}
\hline (35) & \begin{tabular}{c} 
Variedade transgênica em teste no Brasil \\
\cline { 2 - 4 }
\end{tabular} & é & similar à cultivada no Havaí \\
\hline $\begin{array}{c}\text { The kind of Genetically Modified } \\
\text { (Soya Bean) tested in Brazil }\end{array}$ & $\begin{array}{c}\text { Process: } \text { Relational } \\
\text { Attributive }\end{array}$ & Participant: Attribute \\
\hline \multicolumn{2}{|l}{ Participant: Carrier } & \\
\hline to the one grown in Hawaii & Embedded Clause & \\
\hline
\end{tabular}

Environmental changes caused by men or non-green actions commonly actualise the role of the Carrier. These propositions have two functions: 1) to make people aware of the danger they represent, example 34, and 2) to identify their origin and kind, example 35. In both cases, Greenpeace seems to show that the reader and other people involved in such actions are unaware of the real risks involved. In example 34, the reader is present as an entity whose mind feels this unawareness: the non-green action is characterised as "movie stuff" - in Portuguese, a very common allegory for something you do not bother to believe. Example 35 shows a rather different approach: here the genetically modified Soya bean is characterised as the same kind grown abroad.

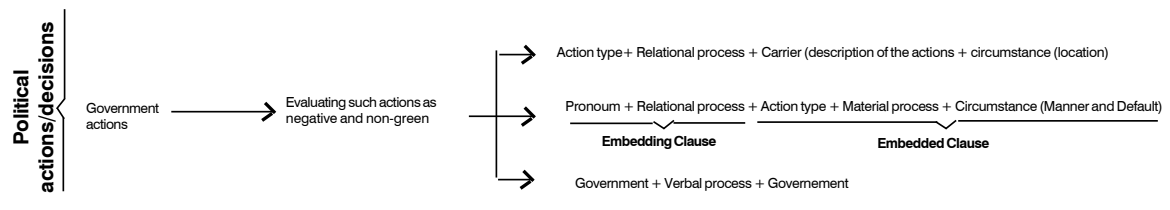

PICTURE 4: Functions of the Government 


\section{Final remarks}

In general terms, this work has contributed to the study of Transitivity in Portuguese in a number of ways. First, the analysis of language as a representation unveils not only specific grammatical features of our language, but also helps us to understand how we organize our system of values. Second, the green-language is still something quite new in Brazil; therefore, very few researchers have laid eyes on the documents used in these communities. The importance of studying such communities is due to the fact that they represent a growing political power in Brazil, which is beginning to influence people's behaviour. Everyday their presence is more constant in the Brazilian media and daily life, inasmuch as their campaigns are coming closer and closer to the general public.

It was possible to understand some elements of the Greenpeace's discourse in this study. The reader seems to be portrayed as someone who is meant to follow orders or commands. As we could see, almost all the processes happen in the imperative mode. The majority of these functions are related to the carrying out of green and protest actions, which are directly aligned with Greenpeace's view. The only counter example is the request for donations, for which this rather directive portrait seems unfit. In the Brazilian culture, asking for donations is much like a submissive act; therefore, such an act must be modalised, since the writer is left in a very uncomfortable and inferior position. Another important matter is the kind of process present in these functions, which is mostly material. That possibly means that the addressee and possible activist-to-be is someone meant to perform only certain actions: there is no proposition that instigates the addressee to take part in the organisation's decisions or future.

In addition to being an active organisation which takes green and political actions, Greenpeace's main functions seem to be to protest against the Government and non-green companies or individuals. Besides that, Greenpeace also tries to show a constant need for donations and affiliations.

Other participants, such as non-Greenpeace activists and natural disasters are present in order to make the addressee aware of the problems, risks and need for participation. The activists are portrayed as people who have sacrificed themselves for the cause, authentic martyrs, while the natural disasters are getting closer and closer, and so must be avoided.

It is important to comment that this study demonstrates the existence of lexicogrammatical patterns, which bring about a system of representation from each participant. In general, most of the choices made in these texts do not appear to be random: choosing who will be responsible for certain 
functions creates patterns of political representation through grammar. This is so, because, as could be observed throughout the text, such patterns are related to a political agenda: grammar is used to show us, the readers, the world that Greenpeace want us to see.

If it may seem obvious that this type of representation occurs in texts like these, it is also important to note that there are few studies that map the grammatical structures used for this purpose. The same is true with relation to grammatical studies in genres like these bulletins; it seems obvious to think that texts like these would work with demands for contact and funding, in addition to extolling certain behaviours or criticizing the decisions of certain political groups. However, it is important to realize that the understanding of these structures seems to lead to a better comprehension of the process of the construction of such texts.

\section{Acknowledgements}

I would like to thank Roberto Carlos Assis (UFPB), Ligia Razera Gallo (FATEC-SP) and Maria Aparecida Gazoti Vallim (IFSP/ FATEC-SP) for proofreading this article.

\section{References}

ARMBRUST, C. As funções das construções passivas em editoriais em português e em inglês: Um estudo a luz da perspectiva sistêmico-funcional (Masters thesis in Applied Linguistics and Language Studies - LAEL). São Paulo: PUCSP, 2006.

ARSIOLLI, M. A. V. A linguagem do meio ambiente numa perspectiva sistêmico funcional. Paper presented at the XVI InPLA, 2007.

BARBOSA, M. D. R. D. S. A. O discurso discente veiculado no contexto escolar: Uma análise do sistema de transitividade. Paper presented at the XVI InPLA, 2007.

BERBER SARDINHA, A. P. Lingüística de Corpus: Histórico e problemática. In: DELTA, vol. 16, number 2, 2000. p. 326-367.

BIBER, D., CONRAD, S., \& REPPEN, R. Corpus linguistics: Investigating language structure and use. Cambridge: Cambridge University Press, 1999.

BRESSANE, T. B. R. Construção de identidade numa empresa em transformação (Masters thesis in Applied Linguistics and Language Studies - LAEL) São Paulo: PUCSP, 2000.

EGGINS, S. An introduction to systemic functional grammar. London: Printer Publishers, 1994. 
FEITOSA, M. P. Uma proposta de anotação de corpora paralelos com base na lingüistica sistêmico-funcional (Masters thesis, Post-graduate studies in Linguistic Studies). Belo Horizonte: UFMG, 2005.

HALLIDAY, M. A. K. Explorations in the functions of language. London: Edward Arnold, 1973.

HALLIDAY, M. A. K. Language as social semiotic. London: Arnold, 1978

HALLIDAY, M. A. K. An introduction to functional grammar. London: Edward Arnold, 1985.

HALLIDAY, M. A. K. Corpus studies and probabilistic grammar. In K. Aijmer \& B. Alternberg (Eds.), English corpus linguistic. London: Longman, 1991.

HALLIDAY, M. A. K. Language as system and language as instance: The corpus as a theoretical construct. In: Svartivik, J. (Org.), Directions on corpus linguistics. Proceedings of the nobel symposium 82. Berlin: Mouton de Gruyer, 1992a.

HALLIDAY, M. A. K. Some lexicogrammatical features of the zero population growth text. In: Mann, W. C. \& THOMPSON, S. A. (Orgs.), Discourse description: Diverse linguistic analyses of a fund-raising text. Amsterdan: John Benjamim, 1992b.

HALLIDAY, M. A. K. Quantitative studies and probabilities in grammar. In: Hoey, M. (Org.), Data, description, discourse. New York: Harper Collins, 1993.

HALLIDAY, M. A. K. An introduction to functional grammar. $2^{\text {nd }}$ ed. London: Edward Arnold, 1994.

HALLIDAY, M. A. K., \& Matthiessen, C. M. I. M. Construing experience through meaning: A language approach to cognition. London / New York: Continnuum, 1999. HALLIDAY, M. A. K., \& Matthiessen, C. M. I. M. An introduction to functional grammar. 3a ed. London: Edward Arnold, 2004.

HEBERLE, V. M. A representação das experiêcias femininas em editoriais de revistas para mulheres. In: Discurso y Sociedad, vol. 1, number 3, 1999. p. 1-25. KENNEDY, G. An introduction to corpus linguistics. London: Longman, 1998. LEECH, D. The state of the art in corpus linguistics. In: Aijmer, K. \& Altenberg, B. (Orgs.), English corpus linguistics. London: Longman, 1991.

LIMA, S. F. D. 2007. Uma análise do discurso de professores de alunos portadores de necessidades especiais em sala comum e em sala de recursos. Paper presented at the XVI InPLA.

LIMA-LOPES, R. E. Estudos de transitividade em lingua portuguesa: O perfil do gênero cartas de venda (Masters thesis in Applied Linguistics and Language Studies - LAEL). São Paulo: PUCSP, 2001. 
LIMA-LOPES, R. E.. Avaliação de um sistema de marcação textual aplicado à gramática sistêmico-funcional. In: Berber Sardinha, A. P. (Org.). A lingua portuguesa no computador. Campinas: Mercado de Letras, 2005a

LIMA-LOPES, R. E. Levantamento de processos materiais em cartas de venda. In: Trabalhos em Lingüistica Aplicada, vol. 44, number 1, 2005b. p. 133-160. LIMA-LOPES, R. E. D., \& VENTURA, C. S. M. A transitividade em português. In: DIRECT Papers, CEPRIL, PUCSP. Available at <http:// www2.lael.pucsp.br/direct/direct_papers.htm>. Acesso em 10 fev. 2012.

MARTIN, J. R., MATTHIESSEN, C. M. I. M., \& PAINTER, C. Working with functional grammar. London: Arnold, 1997.

MCENERY, T., \& WILSON, A. Corpus linguistics. Edinburgh: Edinburgh University Press, 1996.

RAMOS, R. C. G. Projeção de imagens através de escolhas lingüisticas: Um estudo no contexto empresarial (Doctoral dissertation in Applied Linguistics and Language Studies - LAEL). São Paulo: PUCSP, 1997.

RODRIGUES JUNIOR, A. S. A representação de personagens gays na coletânea de contos stud e em sua tradução as aventuras de um garoto de programa (Doctoral dissertation in Applied Linguistics). Belo Horizonte: UFMG, 2006.

SCOTT, M. R. Wordsmith tools - software for lexical analisys. Oxford: OUP, 1999.

SHIMAZUMI, M.. The knower and the informant in institutional talk: A transitivity perspective (Masters thesis in Linguistics). Liverpool: University of Liverpool, 1996.

SINCLAIR, J. Corpus, concordance, colocation. Oxford: Oxford University Press, 1991 SOBHIE, M. T. B. Relações de poder na representação de mundo do discurso de empresas brasileiras de telecomunicaçôes. Paper presented at the XVI InPLA, 2007. STUBBS, M. Text and corpus analysis. Oxford: Blackwell, 1996.

THOMPSON, G. Introducing functional grammar. London: Edward Arnold, 1996.

THOMPSON, G. Resonance in text. In: Sánchez-Macarro, A. \& Carter, R. (Orgs.). Linguistic choice across genres: Variation in spoken and written English. Amsterdam: John Benjamins, 1998.

THOMPSON, G. Introducing functional grammar. 2 ed. London: Edward Arnold, 2004.

WYATT, R. D. The complete consort dancing together... Interaction in e-mail. (Masters thesis in Applied Linguistics and Language Studies - LAEL). São Paulo: PUCSP, São Paulo, 1997.

Recebido em 01/07/2013. Aprovado em 31/01/2014. 